\title{
The Removal of Ibuprofen Drugs Residues from Municipal Wastewater by Moringa Oleifera Seeds
}

\author{
Ghayda Y. Al-Kindi ${ }^{*}$, Husam A. Al-Haidri ${ }^{2}$ \\ 1 Civil Engineering, University of Technology, Baghdad, Iraq \\ 2 Al Rafidain University College, Baghdad, Iraq \\ * Corresponding author's e-mail: Al.kindi.ghydaa@gmail.com
}

\begin{abstract}
Municipal wastewater may contain residues of different drugs causing severe chemical contamination of water bodies. However, the microbial degradation of Wastewater Treatment Plants (WWTP) may not eliminate such drug residues completely. The current work was designed to remove the Ibuprofen drug residues by using the $\mathrm{Mo}$ ringa Oleifera seeds. Various testing methods such as Brunauer, Emmett and Teller (BET), Transmission Electron Microscopy (TEM), scanning electron microscopy (SEM), Fourier transform infrared spectroscopy (FT-IR) were applied to assess the efficiency of such plant seeds in bioremoval of ibuprofen residues from municipal wastewater The batch reactor was used to find the optimum operating conditions using various parameters with different $\mathrm{pH}$ values, duration time, Ibuprofen concentration and various quantities of plant seeds. In the batch reactor, the operation conditions were: $\mathrm{pH}$ 7, duration time $150 \mathrm{~min}$, Ibuprofen dose of $1000 \mathrm{mg} / \mathrm{l}$, activated adsorbents and Moringa Oleifera seeds in the amount of $1000 \mathrm{mg} / \mathrm{l}$. Moreover, the packed bed reactor was used to examine different parameters such as initial Ibuprofen concentration, flow rate and bed depth for 6 hours. It was found that the best conditions were $2 \mathrm{~cm}$ depth, and $25 \mathrm{l} / \mathrm{hr}$ flow rate. Meanwhile, the kinetic constants were studied by adsorption equilibrium with the isothermal Langmuir and Freundlich models. The best results were shown with the Freundlich isotherm, and the first pseudo order was more suitable for the removal of Ibuprofen by adsorbed activation of Moringa Oleifera seeds.
\end{abstract}

Keywords: adsorption, activated $M$. Oleifera, Batch reactor, Ibuprofen, packed bed reactor.

\section{INTRODUCTION}

It has been reported that the residues of various pharmaceuticals and xenobiotic compounds were found in drinking and wastewaters are another public health concern (Ippolito et al., 2011; Touraud et al., 2011; Szymonik et al., 2017). Little is known about the potential chronic health effects associated with long-term ingestion of mixtures of these compounds through drinking water (Kümmerer, 2001; Patneedi and Prasadu, 2015). However, the occurrence of such pharmaceuticals drugs residues in water is due to pharmaceutical industry waste, personal hygiene products, hospital waste and therapeutic drugs (Hee-Jong and Seong-Ho, 2011). It has been well documented that such drug residues had a significant impact on both public health and environment
(Yao et al., 2010; Proesser and Sibly, 2015; Adegoke et al., 2018).

The residues of pharmaceutically active compounds (PhACs) and related contaminants were investigated thoroughly worldwide (Lin et al., 2018; He et al., 2018; Omar et al., 2019; Duan et al., 2020). A detailed work (Heberer et al., 2002) has examined a new long-term monitoring program of sewage, surface, ground- and drinking water and found that in the course of the monitoring program, PhACs and some other polar compounds were detected at the concentrations up to the micro $\mathrm{g} / \mathrm{L}$-level in all compartments of the Berlin water cycle.

However, various studies have focused on the removal of ibuprofen and other pharmaceutical residues from fresh and wastewaters by using various techniques such as chemical coagulation 
(Vieno et al., 2006), aerobic and anaerobic process (Drewes, 2007), membrane bioreactor (Smook et al., 2008), microbial materials (Langenhoff et al., 2013), electrochemically generated ferrate (Ljilian et al., 2016), Ozonation process (Oghazyan et al., 2017); activated carbon (Nourmoradi et al., 2018), advanced oxidation process (Soudabeh et al., 2018), and plant materials (Leon et al., 2019).

On the other hand, M. oleifera seeds were used intensively in water purification (Amagloh and Benang, 2009), river water disinfection (Ali et al., 2019), water treatment (Ali et al., 2009; Tan et al., 2013; Okuda and Ali,2018; Narender et al., 2019), wastewater treatment (Ramesh and Mekala, 2018) and as biosorbent for the removal of fluoride (Agnihotri et al., 2013), various heavy metals (Beltran and Sanchez-Martin, 2008; Limmatvapirat et al., 2015; Abbas, 2018) and the toxic pollutants (Shirani et al., 2018) from all water types.

The M. Oleifera (Moringaceae) plant belongs to the Moringa genus (Morton, 1991). This plant is now cultivated in all tropical and subtropical regions (Ali et al., 2009). This is due to its resistance to different climates, as well as poor and moderately dry soils (Ali et al., 2009). It reaches $15 \mathrm{~m}$ in height, with a diameter of $20-40 \mathrm{~cm}$ (Odee, 1998). Many parts of the plant show pharmacological properties, recognized by popular use and corroborated by the scientific community while other parts of the plant (seeds and leaves) are regarded as low cost and environmentally sound biosorbents (Ali et al., 2015).

Ibuprofen drug, a carboxylic acid. Anti-inflammatory drugs or NSAIDs are frequently used to relieve certain pains. The Ibuprofen medicine has a powdery white appearance and is produced in the form of capsules, tablets, or powder (Carlo, 2013; Pehlic et al., 2013).
Therefore, the current work was designed to use the Moringa Oleifera seeds as biosorbent for the removal of Ibuprofen drug residues from municipal wastewater.

\section{MATERIALS AND METHODS}

\section{Preparation of activated carbon}

M. Oleifera seed pods were collected and washed thoroughly with distilled water and dried to constant weight under sun light. Thereafter, the seed pods were ground and sieved to a size of $106 \mu \mathrm{m}$, left to dry in an air oven at $105^{\circ} \mathrm{C}$ for $6 \mathrm{~h}$. Finally, they were stored in vacuum desiccators.

According to the procedure in ASTM, D 4442 for moisture content, the activating carbon of $M$. Oleifera seed (ACMO) was prepared following the previous work (Abdallah, 2017). After pretreatment, zinc chloride $\left(\mathrm{ZnCl}_{2}\right)$ was added to the chemical activation method, as follows:

The sulfuric acid $\left(\mathrm{H}_{2} \mathrm{SO}_{4}\right)$ was used to activate the raw material with ratio $1: 10 ; 60 \mathrm{~g}$ of raw material was weighted and impregnated in $600 \mathrm{ml}$ $10 \% \mathrm{H}_{2} \mathrm{SO}_{4}(\mathrm{v} / \mathrm{v})$ and $10 \% \mathrm{ZnCl}_{2}(\mathrm{w} / \mathrm{v})$ for 24 hours with continuous mixing then left to dry at $100-105^{\circ} \mathrm{C}$ in oven and stored until it was used as shown in Figure 1. (Dahham, 2018).

The experimental work consisted of two parts where the first was performed using a batch reactor to study the operation conditions and the second used a packed bed reactor to study the breakthrough.

\section{Batch Experiments}

The different adsorption experiments were carried out in a batch reactor to obtain the best

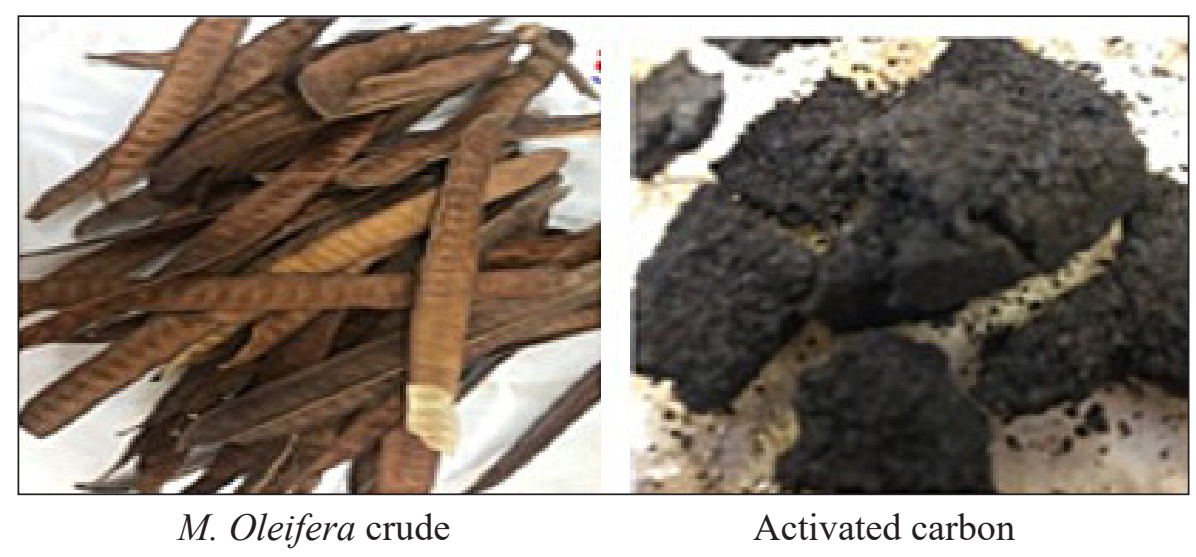

Fig. 1. M. oleifera crude before and after activated carbon 
operation conditions, such as Ibuprofen concentration $(100,250,500,1000 \mathrm{mg})$, adsorbent material $(100,250,500,1000 \mathrm{mg})$ and $\mathrm{pH}(2$, $5,7,9)$. The tests were performed in a beaker with the capacity of $1 \mathrm{~L}$ with rotation speed of $200 \mathrm{rpm}$ for detention time 3 hour at room temperature of $22^{\circ} \mathrm{C}$.

Packed bed reactor was designed and constructed to be used for continuous operation. The reactor consists of a glass tube with $60 \mathrm{~cm}$ length and internal diameter of $2.1 \mathrm{~cm}$. The Ibuprofen solution was pumped using submersible water pump from feed solution to the bed during the valve that controls the flow rate after passing during flow meter. Different sizes of glass beads were used to provide inert zone as well as to catch any impurities and to assist inflow distribution of the reactants through the bed as stated by (Satterfield, et al., 1996), As shown in Figure 2, the flow pattern used in this experimental was down flow and the effluent was collected in a plastic container.

The operation conditions obtained from batch reactor experiment were used in a continuous system (backed bed reactor). The parameters involved different bed heights $(1,1.5$, and $2 \mathrm{~cm})$, different flow rates $(25,30$, and 35$) \mathrm{l} / \mathrm{hr}$, and different Ibuprofen initial concentrations $(100,400$, and $625 \mathrm{mg} / \mathrm{l})$. The experiment was performed at room temperature. The sample was withdrawn from effluent each 30 minutes, filtered and stored to analyze later. The high performance liquid chromatography (HPLC) instrument was used to measure Ibuprofen concentration.

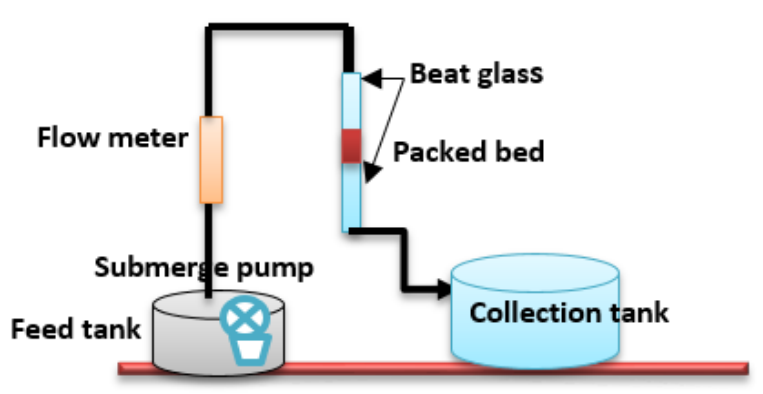

Fig. 2. Schematic diagram of the packed bed system

\section{RESULTS AND DISCUSSION}

\section{BET Instrument Results}

Many factors are important on adsorbent process one of them surface area, Table 1 shows the results of M. oleifera seed activated carbon surface area.

The results of BET instrument show that there was a clear increase in the surface area of activated $M$. oleifera compared to normal seeds. According to the International Union of Pure and Applied Chemistry (Nicoleta et al., 2013), the mesoporous (20 to $500 \mathrm{~nm}$ ) was the characteristic of the activated $M$. oleifera pore size. The chemical composition of the $M$. oleifera seed, and the activation during Transmission Electron Microscopy (TEM) test are given in Tables 2 and 3, while the results of Energy Dispersive Spectroscopy (EDS) are presented in Figures 3 and 4. It was observed that sulfur, and phosphorus and nitrogen appeared in certain amounts, but these quantities were decreased after the carbonization process where the carbon reduction during carbonization process was due to the oxidation of the organic content.

In the images of the M. oleifera before and after activation during the scanning electron microscopy (SEM) test, which are shown in Figures $5 \mathrm{a}-\mathrm{b}$ as well as $6 \mathrm{a}-\mathrm{b}$, the pores and surface roughness in different magnification also show the boundary of crystals regions, different materials that are mixed with nanomaterials in different sizes.

From Fourier transform infrared spectroscopy (FT-IR), the IR spectrum of natural and activated $M$. oleifera with function groups are shown in Table 4 and in Figures 7 and 8.

The results of FT-IR spectrum of natural and activated M. oleifera are shown in Figures 7 and 8. A wide function group range was about 3912.50 $3282.84 \mathrm{~cm}^{-1}$ but low peaks were attributed to the surface hydroxyl group and chemisorbed water. The narrow peak varied from $2331.92 \mathrm{~cm}^{-1}$ to $2312.65 \mathrm{~cm}^{-1}$ and hydroxyl group from $1905.09 \mathrm{~cm}^{-1}$ to $1789.94 \mathrm{~cm}^{-1}$ that between two groups which

Table 1. BET Instrument results

\begin{tabular}{|c|c|c|c|c|c|c|c|}
\hline \multirow{2}{*}{ Adsorbent } & \multicolumn{3}{|c|}{ Surface area $\left(\mathrm{m}^{2} / \mathrm{gm}\right)$} & \multicolumn{2}{c|}{ Pore volume $\mathrm{cm}^{3} / \mathrm{gm}(\AA)$} & \multicolumn{2}{c|}{ Pore size } \\
\cline { 2 - 7 } & before & after & $\begin{array}{c}\text { after packed } \\
\text { bed reactor }\end{array}$ & before & after & & \\
\hline $\begin{array}{c}\text { M. oleifera seed activated } \\
\text { carbon }\end{array}$ & 612 & 720 & 250 & - & 0.88739 & - & $30.029 \mathrm{~nm}$ \\
\hline
\end{tabular}




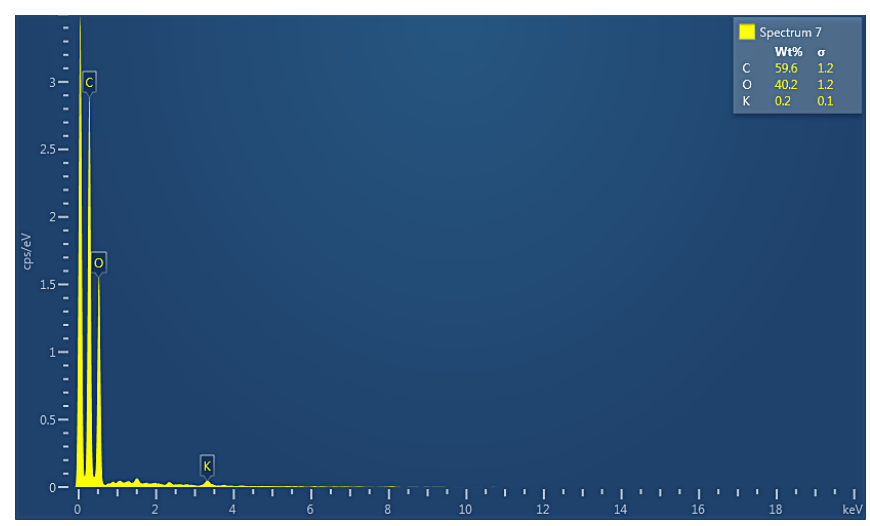

Fig. 3. EDS for natural M. oleifera

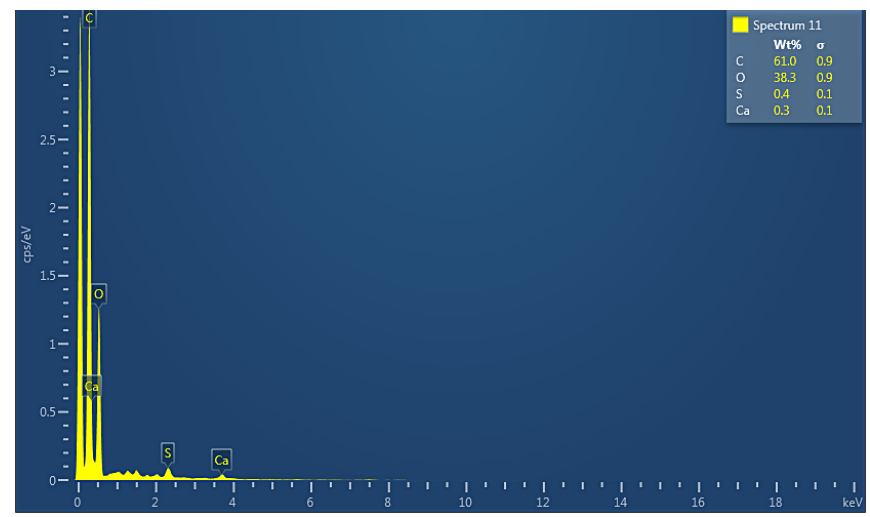

Fig. 4. EDS for active of M. oleifera
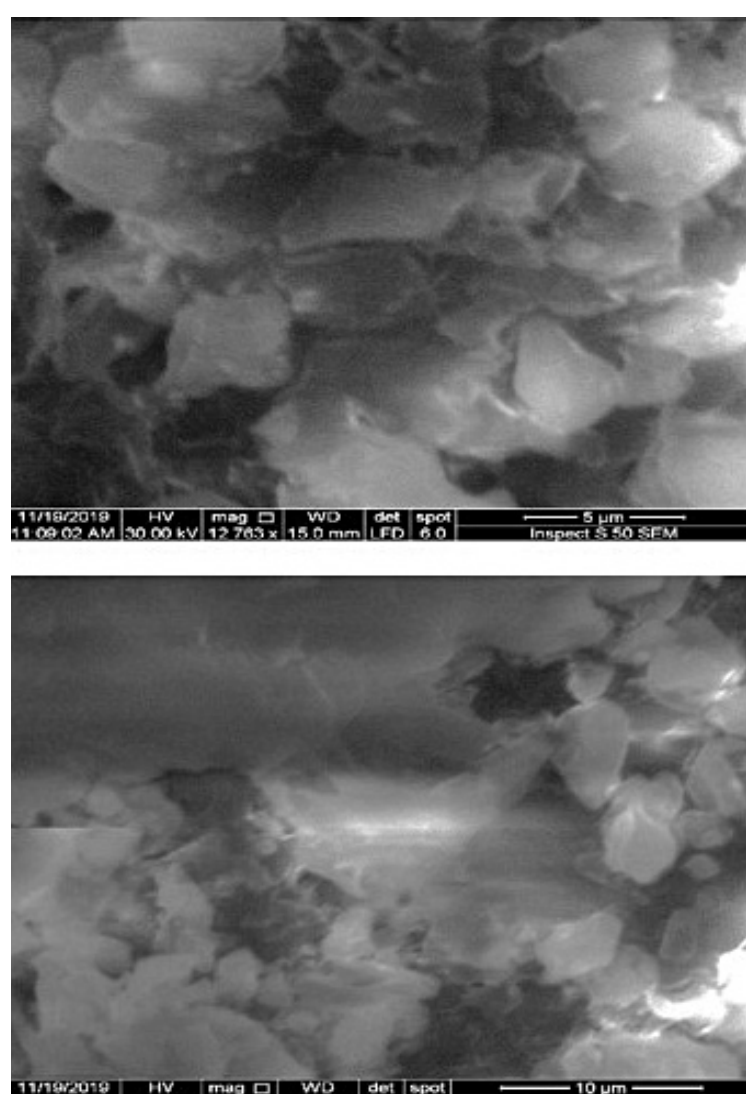

Fig. 5. SEM image for natural $M$. Oleifera with magnification of (a) (5 $\mu \mathrm{m}$ scale), (b) $(10 \mu \mathrm{m}$ scale)
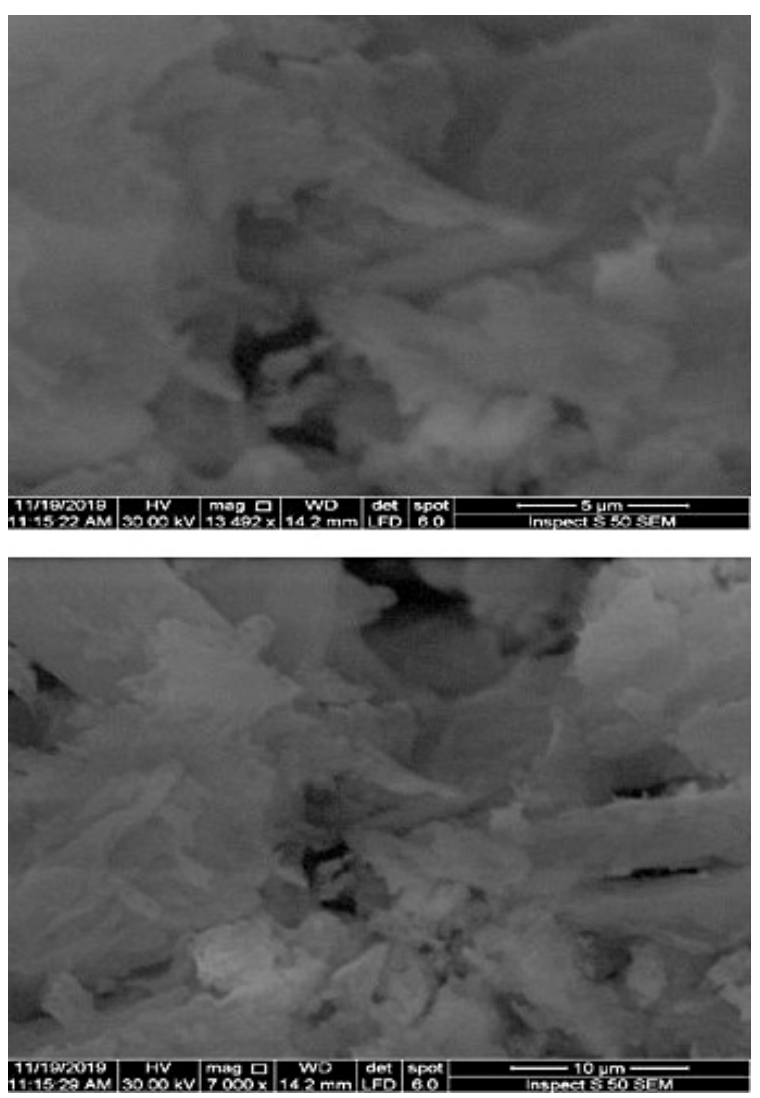

Fig. 6. SEM image for active of M. Oleifera with magnification of (a) (5 $\mu \mathrm{m}$ scale), (b) (10 $\mu \mathrm{m}$ scale) 
Table 2. TEM for natural $M$. oleifera

\begin{tabular}{|c|c|c|}
\hline Spectrum 7 & $\mathrm{Wt} \%$ & $\sigma$ \\
\hline $\mathrm{C}$ & 59.6 & 1.23 \\
\hline $\mathrm{O}$ & 40.2 & 1.22 \\
\hline $\mathrm{K}$ & 0.2 & 0.11 \\
\hline $\mathrm{N}$ & 10.22 & 2.5 \\
\hline $\mathrm{S}$ & 1.95 & 0.12 \\
\hline $\mathrm{P}$ & 1.3 & 0.09 \\
\hline
\end{tabular}

Table 3. TEM for active of $M$. oleifera

\begin{tabular}{|c|c|c|}
\hline Spectrum 11 & Wt\% & $\sigma$ \\
\hline C & 61.0 & 0.9 \\
\hline O & 38.3 & 0.9 \\
\hline K & 0.43 & 0.06 \\
\hline N & 3.2 & 1.81 \\
\hline S & 0.9 & 0.55 \\
\hline P & 0.8 & 0.06 \\
\hline
\end{tabular}

Table 4. The groups of spectrum and this function

\begin{tabular}{|c|l|l|}
\hline \multicolumn{1}{|c|}{ IR spectrum } & \multicolumn{1}{|c|}{ Group function } & \multicolumn{1}{c|}{ Reference } \\
\hline $3903.92 \mathrm{~cm}^{-1}$ to $3745.76 \mathrm{~cm}^{-1}$ & hydroxyl group and chemisorbed water & \\
\hline $3375.43 \mathrm{~cm}^{-1}$ to $2866.22 \mathrm{~cm}^{-1}$ & $\begin{array}{l}\text { the stretching vibration of C-H alkane } \\
\text { group }\end{array}$ & (Kalavathy et al., 2010). \\
\hline $2308.79 \mathrm{~cm}^{-1}$ to $1876.74 \mathrm{~cm}^{-1}$ & C=O ketonic and aldehyde group & $\begin{array}{l}\text { C=C alkene aromatic ring and COO- } \\
\text { Carboxylate groups }\end{array}$ \\
\hline $1649.14 \mathrm{~cm}^{-1}$ to $1066.64 \mathrm{~cm}^{-1}$ & $\begin{array}{l}\text { functional groups, the band can be } \\
\text { assigned to strong C-O bond }\end{array}$ & $\begin{array}{l}\text { the basic structure of Moringa oleifera } \\
\text { (Pehlic et al., 2013) }\end{array}$ \\
\hline $671.13 \mathrm{~cm}^{-1}$ to $499.56 \mathrm{~cm}^{-1}$ & &
\end{tabular}

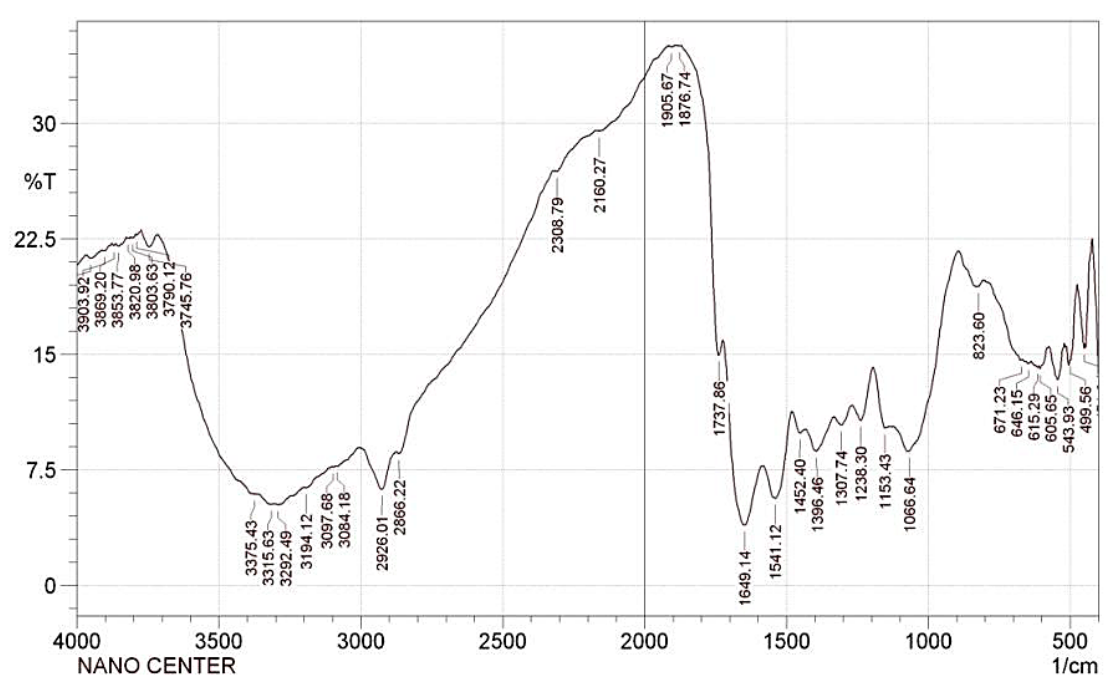

Fig. 7. FT-IR spectrum of the MO seed

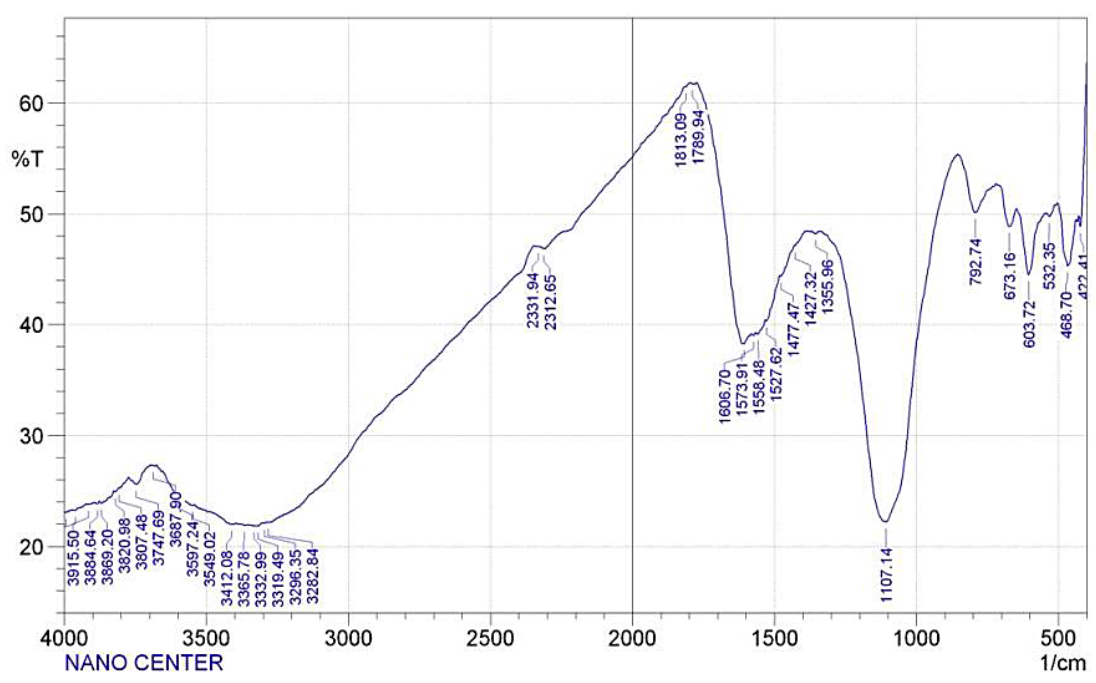

Fig. 8. FT-IR spectrum of the ACMO seed 
were $\mathrm{C}-\mathrm{H}$ and $\mathrm{C}=\mathrm{O} .1606 .70 \mathrm{~cm}^{-1}$ to $1355.96 \mathrm{~cm}^{-1}$ and the range between $\mathrm{C}=\mathrm{O}$ to $\mathrm{C}-\mathrm{O}$ peak appeared in $1107.14 \mathrm{~cm}^{-1}$ (Kalavathy et al., 2010). The last function group of peaks was between $792.74 \mathrm{~cm}^{-1}$ to $422.14 \mathrm{~cm}^{-1}$. The basic structure of $M$. Oleifera was shown in the peaks between $792.74 \mathrm{~cm}^{-1}$ to $422.14 \mathrm{~cm}^{-1}$ (Munajad et al., 2018).

\section{Results of batch reactor}

In order to estimate the Ibuprofen concentration in the experimental work of batch reactor, the Ibuprofen concentration was measured in the wastewater collected from the AL Rustomyia treatment plant -Baghdad city and it was found very high $(650 \mathrm{mg} / \mathrm{l})$. The removal efficiency rate in this station was $60 \%$ due to the use of drugs in large quantities through medical and non-medical prescriptions. Moreover, an animal skin tanning factory (Syadia), near the treatment plant, discharged industrial wastewater carrying significant

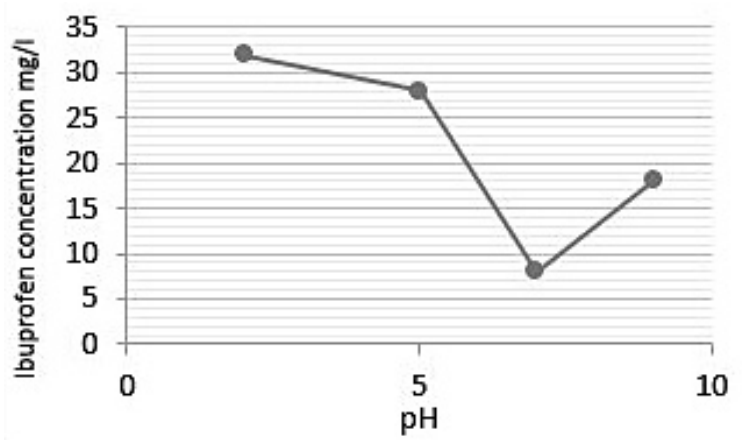

Fig. 9. The relation between $\mathrm{pH}$ and removal of Ibuprofen with different $\mathrm{pH}$ and constant temperature of $22^{\circ} \mathrm{C}$, activated $M$. Oleifera seed concentration $(100 \mathrm{mg} / \mathrm{l})$, and the Ibuprofen concentration in (100 mg/l)

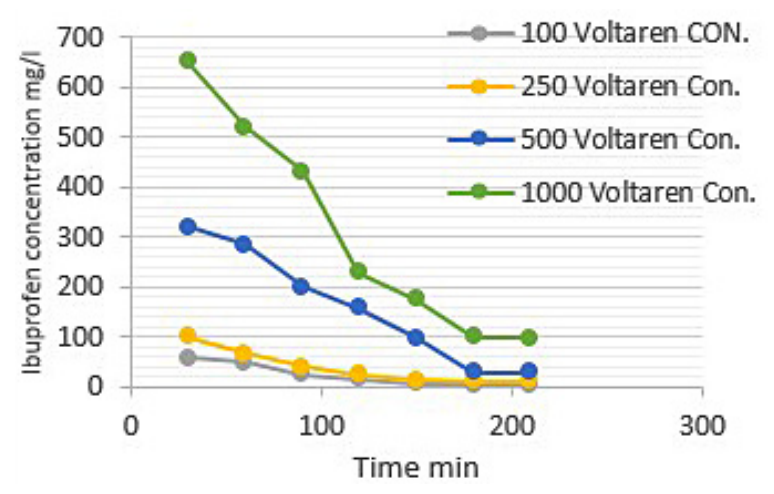

Fig. 11. the relation between time and Ibuprofen concentration, with constant temperature of $22^{\circ} \mathrm{C}$, $\mathrm{pH} 7$ and the activated M. oleifera seed in $(100 \mathrm{mg} / \mathrm{l})$ quantities of Ibuprofen with diclofenac used in tanning animal skins.

\section{Change in $\mathrm{pH}$}

Figures 9 and 10 represent the effect of $\mathrm{pH}$ on the adsorption of Ibuprofen by activated Moringa Oleifera. An improved removal of Ibuprofen along with increasing $\mathrm{pH}$ up to 7 was observed, where at low $\mathrm{pH}$, the adsorbent surface (activated M. oleifera seed powder) was surrounded by hydronium $\left(\mathrm{H}_{3} \mathrm{O}^{+}\right)$ions, and this has decreased the interaction of Ibuprofen with the sites of activated $M$. oleifera seed powder by repulsive forces resulting in low adsorption.

\section{Different Ibuprofen concentration}

In this study, the temperature and $\mathrm{pH}$ were kept constant at $22^{\circ} \mathrm{C}$, and $\mathrm{pH} 7$ while the activation Moringa oleifera equaled to $(100 \mathrm{mg} / \mathrm{l})$, and

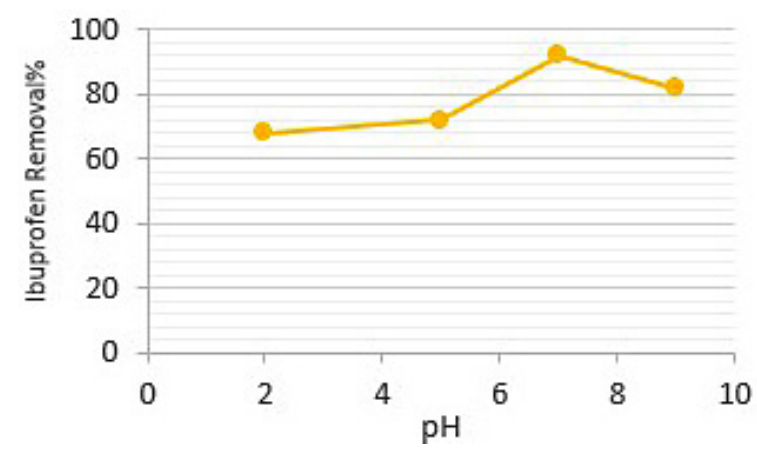

Fig. 10. The relation between $\mathrm{pH}$ and Removal efficiency of Ibuprofen with different $\mathrm{pH}$, and constant temperature of $22^{\circ} \mathrm{C}$, activated $M$. Oleifera seed concentration $(100 \mathrm{mg} / \mathrm{l})$, and the Ibuprofen concentration in $(100 \mathrm{mg} / \mathrm{l})$

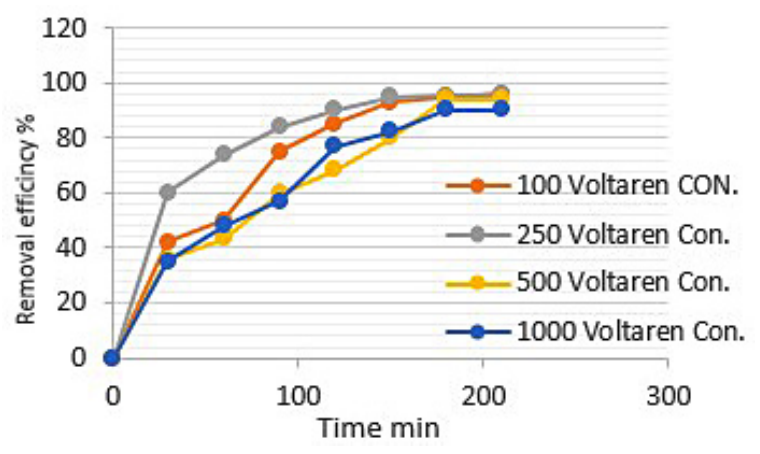

Fig. 12. The ${ }^{\circ}$ between time and removal efficiency of Ibuprofen, with constant temperature of $22^{\circ} \mathrm{C}, \mathrm{pH} 7$ and the activated $M$. oleifera seed in $(100 \mathrm{mg} / \mathrm{l})$ 
only the concentration of Ibuprofen was changed systematically $(100-250-500-1000 \mathrm{mg} / \mathrm{l})$. The Ibuprofen efficiency was calculated by Eq. (1):

$$
\text { Efficiency }=(\mathrm{CO}-\mathrm{Ce}) / \mathrm{CO}
$$

where: $C O=$ Initial Ibuprofen concentration (mg/l).

$\mathrm{Ce}=$ Effluent Ibuprofen concentration $(\mathrm{mg} / \mathrm{l})$.

Figure 11 shows the relation between time (min) with Ibuprofen concentration (mg/l) where the Ibuprofen concentration was decreased with time and the high removal concentration was $250 \mathrm{mg} / \mathrm{l}$. This is due to the available space of activated Moringa Oleifera. However, Figure 12 shows that the Ibuprofen concentration was increased with decreasing the time for all adsorbent tests.

\section{Different mass of Moringa oleifera}

The relationship between time and the concentration of activated $M$. oleifera is shown in Figure 13. The Ibuprofen concentration was decreased with the time causing a clear increase in the removal efficiency, along with the concentration of the adsorbent substance activated M. oleifera, as shown in Figure 14. This was due to the adsorption sites, which were initially opened and the Ibuprofen was interacted easily with the site where the concentration difference between the bulk solution and the solid liquid interface was initially higher and this may lead to higher rate of adsorption observed after 150 minutes. At this time, the reaction has reached the steady state. The best removal efficiency was achieved at the M. oleifera concentration of $1000 \mathrm{mg} /$ liter. Because there was sufficient space for the reaction

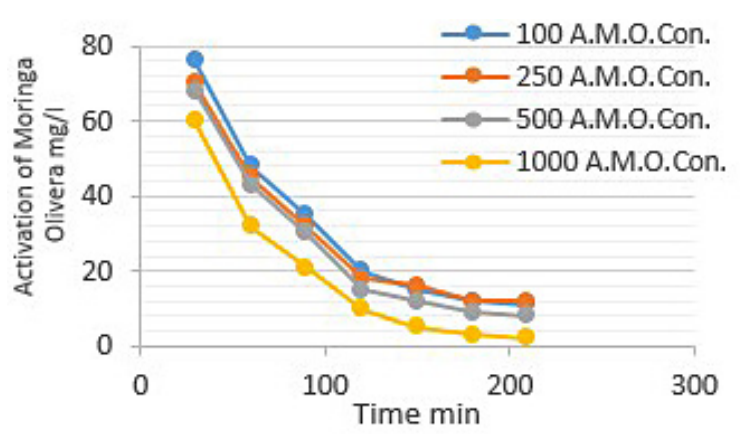

Fig. 13. The relation between time and Ibuprofen concentration, with constant temperature $22^{\circ} \mathrm{C}, \mathrm{pH} 7$ and the Ibuprofen concentration in $(100 \mathrm{mg} / \mathrm{l})$ and the last period, the reaction was completed because the Ibuprofen concentration has become a very small amount. Thus, ensuring uniformed spaces with high interlayer where the Ibuprofen entered to become eliminated (Kurniawan et al., 2006- Sirocki, et al., 2013).

\section{The kinetic models}

An important step in studying the adsorption processes is the study of kinetics (Wang, 2008). The kinetic equation is reported in the $n$-th order of absorption as in equation (2):

$$
(\mathrm{dc} / \mathrm{dt})=-\mathrm{k} \mathrm{C}^{\mathrm{n}}
$$

where: $k$-adsorption rate coefficient,

$C$ - Ibuprofen concentration,

$t$ - time, and

$n$-th - reaction order.

From the previously equation, the pseudofirst and pseudo-second-order kinetic equation were shown as in Equations (3) (4), respectively (Emami et al., 2010):

(First - order) $\log \left(\mathrm{q}_{\mathrm{e}}-\mathrm{q}_{\mathrm{t}}\right)=\log \mathrm{q}_{\mathrm{e}}-\mathrm{K}_{\mathrm{l}} \mathrm{t}$

where: $q t, q_{\mathrm{e}}$ is the adsorbed at time $t$ and equilibrium $(\mathrm{mg} / \mathrm{g})$,

$t$ is the time of adsorption process (min), and,

$k_{1}$, and $k_{2}$ is the rate constant for pseudofirst, and pseudo-second-order reaction, respectively.

$K_{1}$ is a constant (min-1), which is determined by plot $\ln \left(\mathrm{q}_{\mathrm{e}}-\mathrm{q}_{\mathrm{t}}\right)$ versus $\mathrm{t}$.

$$
\text { (Second }- \text { order) } \frac{t}{q t}=\frac{1}{K 2 q e \Lambda 2}+\frac{t}{q e}
$$

The initial sorption rate is defined by the following equation:

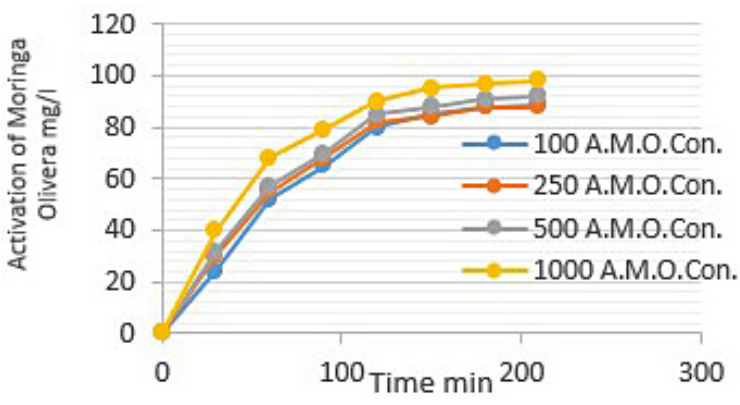

Fig. 14. The relation between time and removal efficiency of Ibuprofen, with constant temperature $22^{\circ} \mathrm{C}, \mathrm{pH} 7$ and the Ibuprofen concentration in $(100 \mathrm{mg} / \mathrm{l})$ 


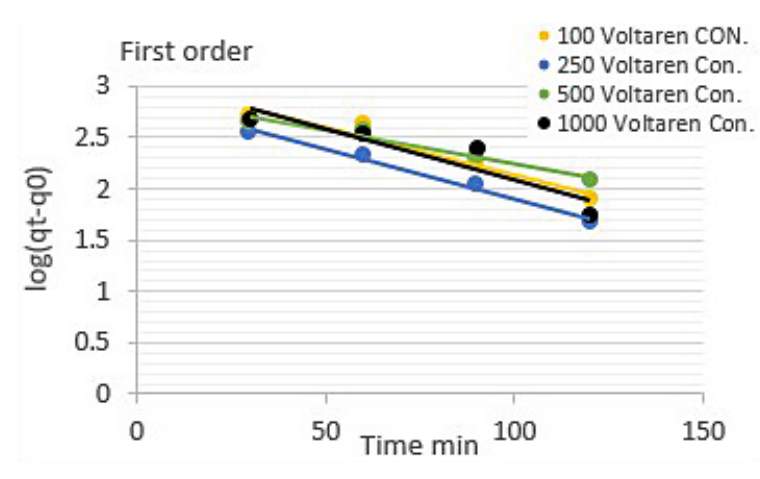

Fig. 15. Linear plots of kinetics data of the first order model at various dosage of Ibuprofen

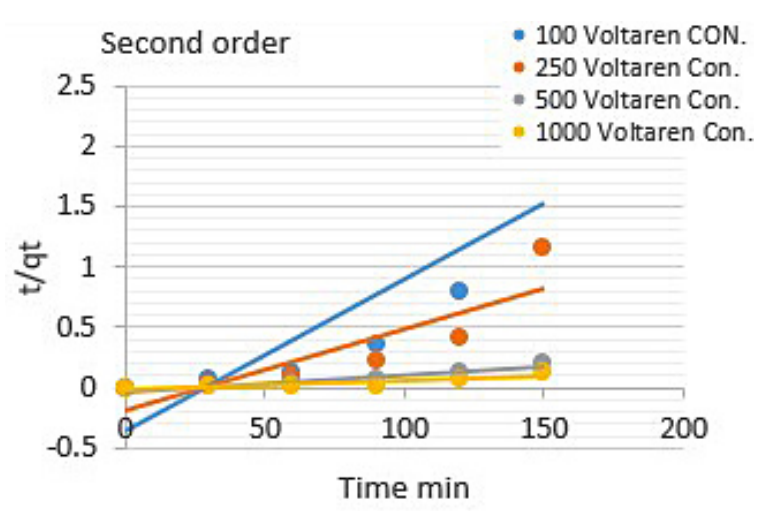

Fig. 16 Linear plots of kinetics data of the second order model at various dosage of Ibuprofen

Table 5. Kinetic parameters

\begin{tabular}{|c|c|c|c|c|c|c|c|}
\hline & \multicolumn{3}{|c|}{ First order } & \multicolumn{3}{|c|}{ Second order } & \multirow[b]{2}{*}{$\begin{array}{l}\text { Calculated eqilb. } \\
\text { uptake qe }\left(\mathrm{mg} \mathrm{g}^{-1}\right)\end{array}$} \\
\hline & $\mathrm{R}^{2}$ & $k_{1}\left(\min ^{-1}\right)$ & \begin{tabular}{|c|} 
calculated eqilb. \\
uptake qe $\left(\mathrm{mg} \mathrm{g}^{-1}\right)$
\end{tabular} & $\begin{array}{c}k_{2} \\
\left(\mathrm{~g} \mathrm{mg}^{-1} \mathrm{~min}^{-1}\right) \\
\end{array}$ & $\begin{array}{c}h \\
\left(\mathrm{mg} \mathrm{g}^{-1} \mathrm{~min}^{-1}\right) \\
\end{array}$ & $\mathrm{R}^{2}$ & \\
\hline 100 & 0.9402 & 0.00286 & 794.3 & 0.003 & 19.2 & 0.8741 & 80 \\
\hline 250 & 0.9887 & 0.0051 & 891.3 & 0.0053 & 107.16 & 0.9339 & 142.8 \\
\hline 500 & 0.9596 & 0.0013 & 501.2 & 0.00147 & 235.2 & 0.7718 & 400 \\
\hline 1000 & 0.8369 & 0.00432 & 398.1 & 0.00123 & 136.6 & 0.8896 & 333.33 \\
\hline
\end{tabular}

$$
\mathrm{h}=k_{2} * q 2^{2}
$$

This kinetic study on different Ibuprofen concentration due to large value of $\mathrm{R}^{2}$

The result $\mathrm{k}$ and $\mathrm{R}^{2}$ for first and second order were shown in Figures 15, 16 and in Table 5. From the results, it was found that the pseudo-first order was the best result because of the high $\mathrm{R}^{2}$.

The results showed that the pseudo-first-order equation has fitted the experimental data well with a correlation coefficient $\left(\mathrm{R}^{2}\right)$ which was more close to one than the second-order. Table 5 shows the result of first-order and second-order models and also to those observed in Figures 15 and 16. The deviation from the straight line of sorption as in the pseudo-first- and second-order model, and

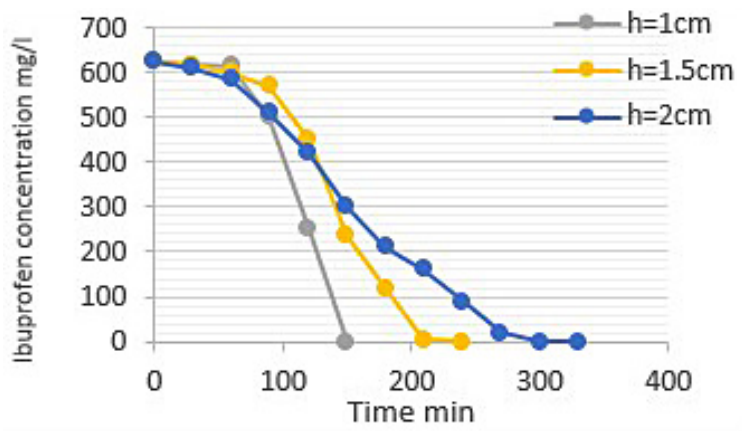

Fig. 17. Ibuprofen concentration adsorption on activated $M$. oleifera seed with different depth and flow rate $25 \mathrm{l} / \mathrm{hr}$. and $\mathrm{pH} 7$ the adsorption in this study was a slow especially in the initial period of the reaction. On the basis of the correlation coefficients, the first-order model was a reaction pathway for sorption of Ibuprofen by activated Moringa oleifera (Kowanga et al., 2016).

\section{Packed bed reactor}

The breakthrough was studied in packed bed reactor and the experimental tests were performed with different parameters such as bed height of adsorbent $(1,1.5,2 \mathrm{~cm})$, initial Ibuprofen concentration $(100-400-625 \mathrm{mg} / \mathrm{l})$, the flow rate $(25-$ $30-351 / \mathrm{hr}$ ), constant $\mathrm{pH}$ up to 7 and temperature of $22^{\circ} \mathrm{C}$.

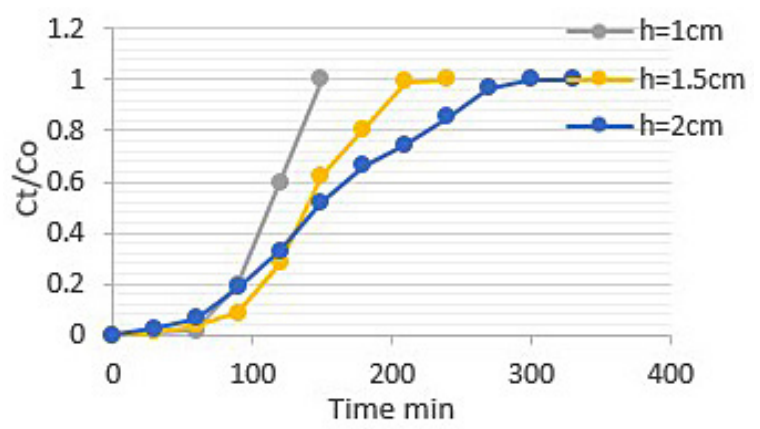

Fig. 18. Breakthrough curve of Ibuprofen adsorption on activated $M$. oleifera seed with different depth and flow rate $25 \mathrm{l} / \mathrm{hr}$. and $\mathrm{pH} 7$ 


\section{Different height bed}

The results showed that the breakthrough was increased along with bed height, as shown in Figures 17 and 18 for Ibuprofen removal efficiency with time. Moreover, it was found that the breakthrough observed in bed height $1 \mathrm{~cm}$ was not clear because the bed was small and not enough to complete adsorption, but in beds of $1.5,2 \mathrm{~cm}$, the breakthrough was very clear due to increase in the surface area for adsorption and increase in detention time that referred to high capacity to adsorb the Ibuprofen solution. These results are supported by those of recent study (Al Ani et al., 2019). The breakthrough has begun approximately from the same time, but it was finished at different times.

\section{Different flow rate}

In order to study the effect of flow rate, different flow rates $(25,30$, and $351 / \mathrm{hr})$ were applied with constant of bed height at $2 \mathrm{~cm}, \mathrm{pH}$ at 7, Ibuprofen

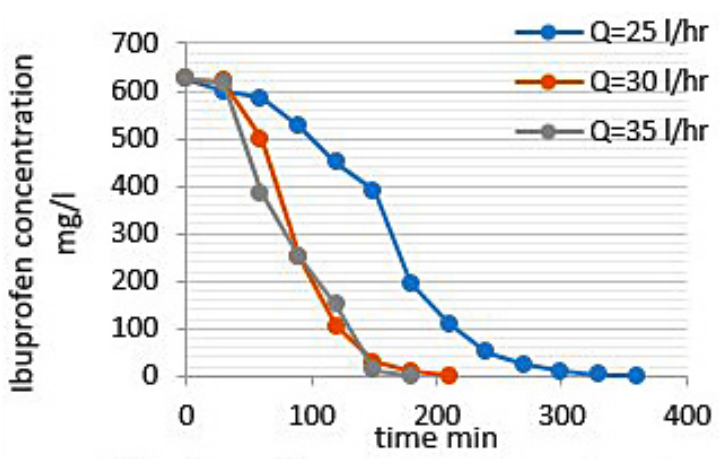

Fig. 19. Ibuprofen concentration adsorption on activated $M$. oleifera seeds with depth $2 \mathrm{~cm}$, and $\mathrm{pH} 7$, Ibuprofen concentration $625 \mathrm{mg}$, and different flow rate

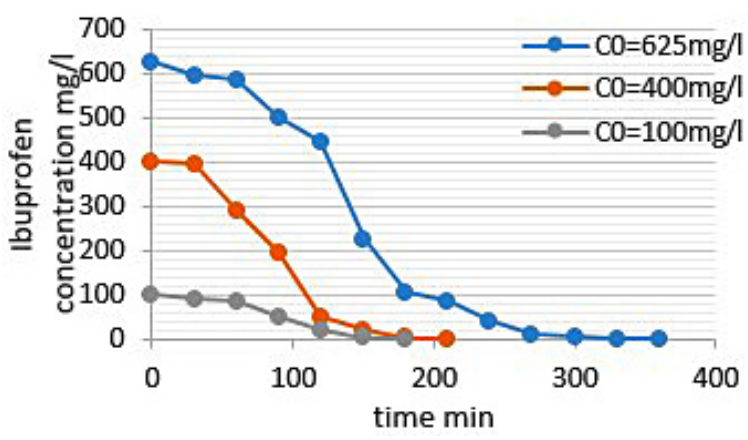

Fig. 21. Ibuprofen concentration adsorption on activated $M$. oleifera seeds with depth $2 \mathrm{~cm}, \mathrm{pH} 7$ and different Ibuprofen concentration concentration at $625 \mathrm{mg} / \mathrm{l}$, and temperature at $22^{\circ} \mathrm{C}$. The effect of changing flow rate is shown in Figure 19. The results showed that with increasing the flow rate, the breakthrough has become steeper depending on resident time of Ibuprofen passing on adsorbed bed. Thus, the residence time was decreased with increasing the flow rate. Additionally, Figure 20 shows that the Ibuprofen concentration was decreased with increasing operation time of the bed for removal and decreasing flow rate.

\section{Different initial Ibuprofen concentrations}

The effect of the initial Ibuprofen concentrations $(100,400,625 \mathrm{mg})$ on breakthrough with other parameter kept constant is shown in Figure 21, where the bed height was $2 \mathrm{~cm}$, flow rate $25 \mathrm{l} / \mathrm{hr}$, $\mathrm{pH} \mathrm{7}$, and temperature $-22^{\circ} \mathrm{C}$. It seems that with increasing the initial Ibuprofen concentration, the breakthrough increased too. Figure 22 shows that the Ibuprofen concentration decreased with time.

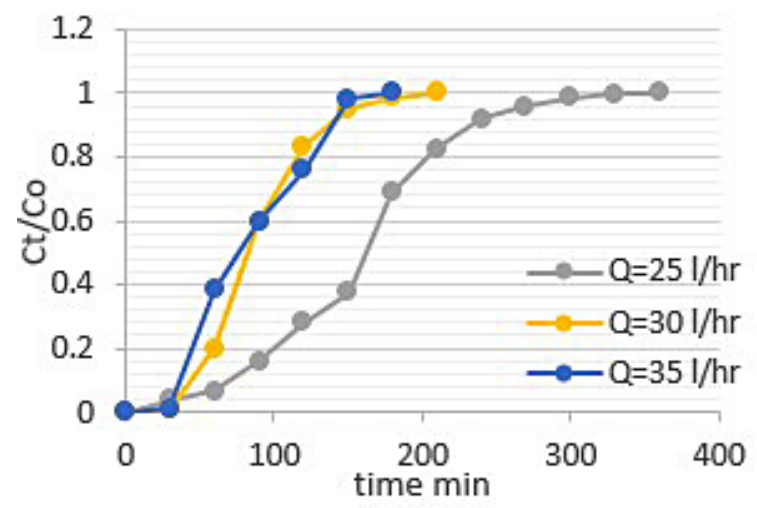

Fig. 20. Breakthrough curve of Ibuprofen adsorption onto activated M. oleifera seeds with depth $2 \mathrm{~cm}$, and $\mathrm{pH} 7$, Ibuprofen concentration $625 \mathrm{mg}$, and different flow rate

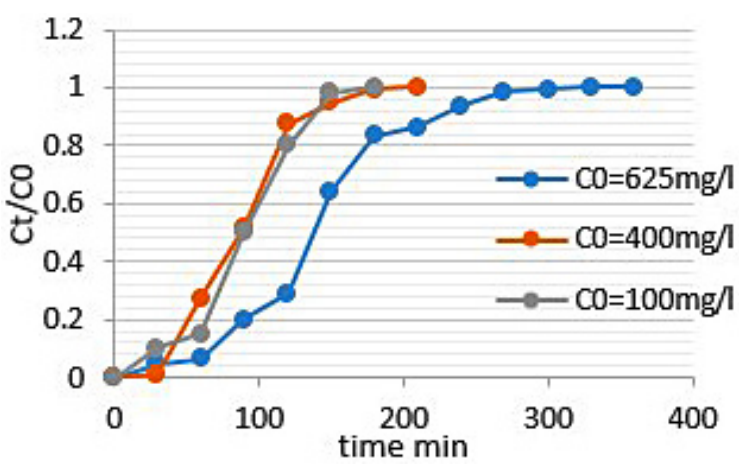

Fig. 22. Breakthrough curve of Ibuprofen adsorption on activated $M$. oleifera seeds with depth $2 \mathrm{~cm}, \mathrm{pH} 7$ and different Ibuprofen concentration 


\section{Kinetic isotherm model}

The isotherm analysis was studied through applying a fitting technology for several isotherm models to achieve a suitable model that it is applied for designing objectives. In the Langmuir and Freundlich adsorption models, the constant of Freundlich equation was determined by slope and the linearized was done by using the equation 5 .

$$
\ln \mathrm{q}_{\mathrm{e}}=\ln \mathrm{K}+\frac{1}{n} \times \ln \mathrm{C}_{\mathrm{e}}
$$

where: $k, n$ constant, $1 / n$ range between $(0-1)$

However, the constant of Langmuir equation was determined by slope, interest linearized by using the equation 7 ,

$$
\frac{1}{q_{e}}=\frac{1}{q_{\max }}+\frac{1}{q_{\max } \cdot b} * \frac{1}{C_{e}}
$$

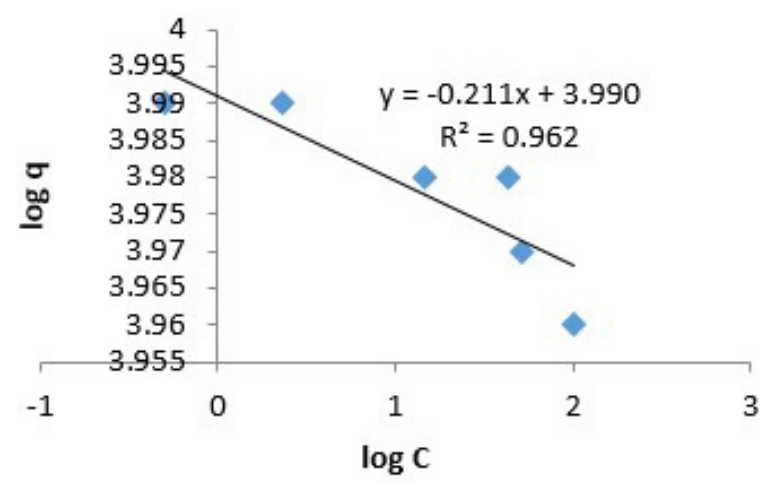

Fig. 23. Freundlich mode $\left(\mathrm{C}_{\mathrm{e}}=\mathrm{mg} / \mathrm{l}\right.$, and $\left.\mathrm{q}_{\mathrm{e}}=\mathrm{mg} / \mathrm{g}\right)$ for Activated Moringa Oleifera seed adsorbent

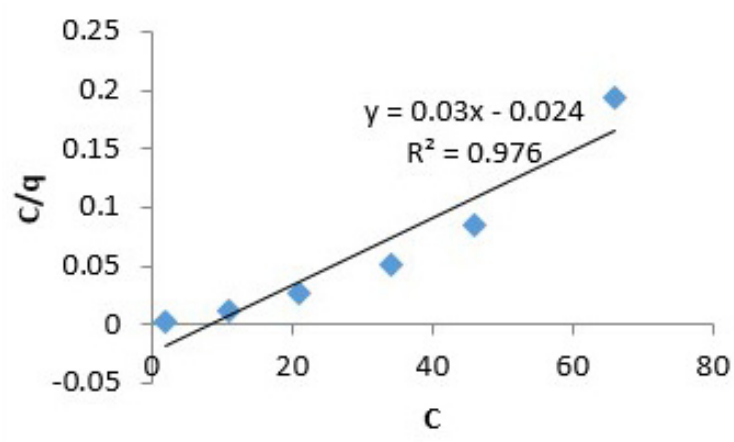

Fig. 24. Langmuir mode $\left(\mathrm{C}_{\mathrm{e}}=\mathrm{mg} / \mathrm{l}\right.$, and $\left.\mathrm{q}_{\mathrm{e}}=\mathrm{mg} / \mathrm{g}\right)$ for Activated Moringa Oleifera seed adsorbent
This equation was used to determine the value of $\mathrm{q}_{\max }(\mathrm{mg} / \mathrm{g})$ and $\mathrm{b}(\mathrm{L} / \mathrm{mg})$ through plot $1 / \mathrm{q}_{\mathrm{e}}$ versus $1 / \mathrm{C}_{\mathrm{e}}$. The activated Moringa oleifera seeds adsorbent through Freundlich adsorption models showed that during R2, the Ibuprofen concentration was more effective on the model, so that the kinetic was adapted to the change in Ibuprofen concentrations.

The activated $M$. oleifera seeds adsorbent through the Langmuir adsorption models showed that the change in the concentrations of activated M. oleifera seed at $100 \mathrm{mg}$ was more effective on Ibuprofen removal, so that the kinetic was adapted on change in weight of activated M.oleifera seed as shown in Figures 23 and 24. The results of the Freundlich and Langmuir model constant are given in Table 6. It was seen that:

- $q_{e}$ which represents the solute obtained in unit mass of local adsorbent was found to be related directly with value of concentration $C_{e}$ that represented the equilibrium concentration

- The type of equilibrium isotherm that considers a favorable type and there due to the high weight of adsorbent for Langmuir and Freundlich which can be applied. Both models give approximately the same results, but the Langmuir model gives slightly higher R2 values.

\section{CONCLUSION}

The activated $M$. oleifera seeds were found to be the best adsorbent and a good alternative, being a cheap adsorbent that can be used for the Ibuprofen removal from wastewater. Using a batch reactor, it was found that the operation conditions were as a follows: $\mathrm{pH} \mathrm{7,} \mathrm{Ibuprofen} \mathrm{concentra-}$ tion $1000 \mathrm{mg} / \mathrm{l}$, adsorbents (activated M. oleifera seed $-1000 \mathrm{mg} / \mathrm{l}$. From the results, the first order was found the best adsorption kinetic result in batch reactor. The break points of the breakthrough curve for adsorbents (activation of $\mathrm{M}$. oleifera seed) increased along with the bed height and initial flow rate. In the case of a continuous reactor, the Freundlich and Langmuir isotherm models were found to be favorable for activation of $M$. oleifera seed as adsorbents.

\begin{tabular}{|c|c|c|c|c|}
\hline \multirow{2}{*}{ Adsorbent } & \multirow{2}{*}{ Models } & \multicolumn{3}{|c|}{ Model constant } \\
\hline & & $\mathrm{R}^{2}$ & $\mathrm{~K}$ & $\mathrm{n}$ \\
\hline \multirow{2}{*}{ M. Oleifera seeds activated Carbone } & Frundlish model & 0.962 & 0.59 & $\begin{array}{c}4.7 \\
1 / n=0.212\end{array}$ \\
\hline & Langmuir model & 0.976 & $Q=0.33$ & $b=0.013$ \\
\hline
\end{tabular}

Table 6. Freundlich and Langmuir model constant 


\section{REFERENCES}

1. Abbas, M. (2018). The use of Moringa Oleifera Seeds for the removal of Heavy Metals from Wastewater. Nigerian Journal of Engineering Science Research (NIJESR).1(1): 08-13.

2. Abdallah, A,A.: Jazmati, R.R. and Refaai R. (2017). Structural and Optical Properties of $\mathrm{ZnO}$ Thin Films. Journal of Nano- and Electronic Physics 1:1.

3. Adegoke, A, A; Amoah, I.D.; Stenstrom, T.A.; Verbyla, M.E. and Mihelcic, J.R. (2018). Epidemiological Evidence and Health Risks Associated with Agricultural Reuse of Partially Treated and Untreated Wastewater: A Review. Front Public Health. 6,337.

4. Alani, F.H, AL-Kindi GY, Al-Bidri N.Kh. (2019) Diclofenac removal from wastewater by Iraqi pillared clay. Journal of Engineering \& Technology 37(2)) 24-28.

5. Ali, E.N., Muyibi, S.A., Salleh, H.M., Salleh, M. R.M., \& Alam, M.Z. (2009). Moringa Oleifera Seeds As Natural Coagulant for Water Treatment. In Thirteen International Water Technology Conference, IWTC, Hurghada, Egypt, 13, 163-168.

6. Ali, E.N.; Alfarra, S.R.; Yusoff, M.M., and Rahman, M.L. (2015). Environmentally Friendly Biosorbent from Moringa Oleifera Leaves for Water Treatment. International Journal of Environmental Science and Development.6(3): 165-169.

7. Ali, M. Muhammad, S.A.; Idris, S.I. and Ibrahim, U.I. (2019). Disinfection effect of Moringa oleifera seed extracts against bacteria isolated from river water. EMBO. 2(5): 263-268.

8. Amagloh, F.K. and Benang, A. (2009). Effectiveness of Moringa oleifera seed as coagulant for water purification. African Journal of Agricultural Research.4 (1): 119-123.

9. Beltran, J. and Sanchez-Martin, J. (2008). Heavy metals removal from surface water with Moringa oleifera seed extract as flocculant agent. Fresenius Environmental Bulletin.17(12):2134-2140.

10. Carlo, B.; Donna M. Huryn, Amos B. Smith III (2013)" Carboxylic Acid (Bio) Isosteres in Drug Design" Chem. Med. Chem. 8(3):385-395.

11. Connors, S.; Lanza, R.; Sirocki, AQ. and Bergendahl, J. (2013). Removal of Ibuprofen from Drinking Water using Adsorption. Major Qualifying Project completed in partial fulfillment of the Bachelor of Science Degree at Worcester Polytechnic Institute, Worcester, MA.

12. Dahham, N. Kh. (2018)" Diclofenac removal comparison from wastewater by adsorption onto pillared clay, activated carbon and locally produced adsorbent" M.Sc. in Environment Engineering, University of technology.

13. Drewes, J.E. (2007). Removal of pharmaceutical residues during wastewater treatment. Comprehensive Analytical Chemistry. 50:427-449
14. Duan, L.; BinWang, Y. Z. ; Cagnetta, G.; Deng, S.; Huang, J. : Wang, Y. and Yu, G. (2020). Characteristics of pharmaceutically active compounds in surface water in Beijing, China: Occurrence, spatial distribution and biennial variation from 2013 to 2017. Environmental Pollution.264: 114753

15. Emami, F.A.R. Tehrani-Bagha, K.F. Gharanjig, M. Menger, 2010. Kinetic study of the factors controlling Fenton-promoted destruction of a nonbiodegradable dye, Journal of Desalination, 257: 124-128.

16. He, Y.; Sutton, N.B.; Huub, Y.; Rijnaarts, H.M. and Langenhoff, A.A.M. (2018). Fate and distribution of pharmaceutically active compounds in mesocosm constructed wetlands. Journal of Hazardous Materials. 357:198-106.

17. Heberer, Th.; Reddersen, K. and Mechlinski, A. (2002). From municipal sewage to drinking water: fate and removal of pharmaceutical residues in the aquatic environment in urban areas. Water Science and Technology. 46(3): 81-88.

18. Hee-Jong, C. and Seong-Ho, J. (2011). Occurrence of Residual Pharmaceuticals and Fate, Residue and Toxic Effect in Drinking Water Resources. J. of Korean Society of Environmental Engineers. 33(6): 453-479.

19. Ippolito, J; Barbarick, K.A. Elliott, H.A. (2011). Drinking Water Treatment Residuals: A Review of Recent Uses. Journal of Environmental Quality, 40(1):1-1.

20. Kalavathy, H. M., Karthikeyan T., Rajgopal, S., \& Miranda S. (2010) Kinetic and isotherm studies of $\mathrm{Cu}$ (II) adsorption onto $\mathrm{H} 3 \mathrm{PO} 4$ - activated rubber wood sawdust. Journal of Colloid and Interface Science, 292, 354-362.

21. Kawanga, KD, Gatebe E, Mauti GO, Mauti EM. 2016. Kinetic, sorption isotherms, pseudo-first-order model and pseudo-second-order model studies of $\mathrm{Cu}(\mathrm{II})$ and $\mathrm{Pb}(\mathrm{II})$ using defatted Moringa Oleifera seed powder. The Journal of Phytopharmacology; $5(2): 71-78$

22. Kuriniawan, T.A., Chan G.Y.S., Lo W. H. and Babel S. (2006) "PhysicoChemical Treatment Techniques for Wastewater Laden with Heavy Metals". Journal of Chemical Engineering; 118: 83-98.

23. Langenhoff, A.; Inderfurth, N.; Veuskens, T.; Schraa, G.; Blockland, M.; Kujawa-Roeleved, K. and Rijnaarts, H. (2013). Microbial Removal of the Pharmaceutical Compounds Ibuprofen and Diclofenac from Wastewater. Research Article - Open Access. |Article ID 325806 | https://doi. org/10.1155/2013/325806.

24. Leon, G.R.; Aldas, M.B.; Guerrero, V.H. and Landazuri, A.C. (2019) Caffeine and irgasan removal from water using bamboo, laurel and moringa residues impregnated with commercial $\mathrm{TiO} 2$ nanoparticles. International Materials Research Congress XXVIII. 4(64): 3553-3567.

25. Lin, H.; Chen, L.; Li, H.: Luo, Z.; Lu, J. and Yang, Z. (2018). Pharmaceutically active compounds in the Xiangjiang River, China: Distribution pattern, 
source apportionment, and risk assessment. Science of the Total Environment.636:875-984.

26. Ljilian, N.; Milan, C.; Milena, T. (2016). Ibuprofen removal from aqueous solution by in situ electrochemically generated ferrate(VI): proof-of-principle. Water Science and Technology.73(2): 389-395.

27. Limmatvapirat, C.; Limmatvapirat, S.; Charoenteeraboon, J.; Wessapan, C.; Kumsum, A.; Jenwithhavaamomwech, S. and Luangthuwapranit, P. (2015). Comparison of Eleven Heavy Metals in Moringa Oleifera Lam. Products. Indian J. Pharm. Sci. 77(4): 485-490.

28. Morton, J.F. (1991). The horseradish tree, Moringa pterygosperma (Moringaceae): A boon to arid lands? Economic Botany, 45(3), 318-333.

29. Munajad, A, Subroto C, Suwarno (2018) Fourier transform infrared (FTIR) spectroscopy analysis of transformer paper in mineral oil-paper composite insulation under accelerated thermal aging. Journal of Energies 11(2), 364 https://doi.org/10.3390/ en11020364.

30. Narender, B.R.; Akshitha, K; Prashanth, A.; Reddy, Y.S. and Saketh, A. (2019). Treatment of water with Moringa Oleifera as a coagulant. World J. of Pharmacy and Pharmaceutical Science. 8(7): 996-1016.

31. Nicoleta, P. Rosu A-M, Aru VA, Nistor DI, Siminiceanu I (2013) Chemically modified clays used for environmental quality. Journal of Engineering Studies and Research, 19(4), 52-58.

32. Nourmoradi, H.; Moghadam, K.F.; Jafari, A. and Kamarehie, B. (2018). Removal of Acetaminophen and Ibuprofen from Aqueous Solutions by Activated Carbon Derived from Quercns Branfi (Oak) Acron as a low-cost Biosorbent.Journal of Environmental Chemical Engineering, 6(6): 6807-6815.

33. Odee, D. (1998). Forest biotechnology research in drylands of Kenya: The development of Moringa species. Dryl Biodivers, 12(3), 7-8.

34. Oghazyan, A.; Yazdanbakhsh, A.; Eslami, A. and Asadi, A. (2017). Removal of Ibuprofen from aqueous solutions by Ozonation process. Open Journal System, 4(3):

35. Okuda, T. and Ali, E.N. (2018). Application of Moringa oleifera Plant in Water Treatment. Water and Wastewater Treatment Technologies. 63-79.

36. Omar, T.F.T.; Aris, A.Z.; Yousoff, F.M., Mustafa, S. 2019. Risk assessment of pharmaceutically active compounds (PhACs) in the Klang River estuary, Malaysia. Environmental Geochemistry and Health. 41:211-223.

37. Patneedi, C.B. and Prasadu, K.D. (2015). Impact of Pharmaceutical Wastes on Human Life and Environment. RASYAN J. Chem.8(1): 67-70.

38. Pehlic, E., Bajramovic Đ. Mirza N. Majda S.,(2013) Propionic acid derivatives synthesis as cyclooxygenase-1 (COX-1) and cyclooxygenase-2 (COX-2) inhibitors by rheumatoid arthritis, Balkan Journal of
Health Science, 1(1); 6-11.

39. Proesser, R.S. and Sibley, P.K. (2015). Human health risk assessment of pharmaceuticals and personal care products in plant tissue due to biosolids and maure amendments, and wastewater irrigation. Environmental International, 75:223-233.

40. Ramesh, S. and Mekala, L (2018). Treatment of Textile Wastewater Using Moringa Oleifera and Tamarindus indica. International Research Journal of Engineering and Technology. 6(171): 3891-3895.

41. Satterfield, C. N. (1996). Heterogeneous Catalysis in Industrial Practice. Boston MA: Krieger Company

42. Sirocki, A.R., Lanza, R.A., \& Connors, S.C. (2013). Removal of Ibuprofen from Drinking Water using Adsorption. Retrieved from https://digitalcommons. wpi.edu/mqp-all/2716.

43. Shirani, Z.; Santhosh, C.; Iqbal, J. and Bhatnagi, A. 2018. Waste Moringa oleifera seed pods as green sorbent for efficient removal of toxic aquatic pollutants. Journal of Environmental Management. 227: 95-106.

44. Soudabeh, S.; Pasi, T.; Narendra, K. and Kari, E. (2018). Advanced oxidation process for the removal of ibuprofen from aqueous solution: a non-catalytic and catalytic ozonation study in a semi-batch reactor. Applied Catalysis B: Environment. 230: 77-90.

45. Smook, T.M.; Zho, H. and Zytner, R.G. (2008). Removal of ibuprofen from wastewater: comparing biodegradation in conventional, membrane bioreactor, and biological nutrient removal treatment systems. Water Science and Technology. 57(1): 1-8.

46. Szymonik, A.; Lach, J. and Malinska, K. (2017). Fate and Removal of Pharmaceuticals and Illegal Drugs Present in Drinking Water and Wastewater. Ecological Chemistry and Engineering S, 24(1):65-84.

47. Tan C.S., Makky E.A., Ali, E.N. (2013). Impact of Moringa oleifera in Waste Water Treatment. Conference: National Conference on Industry-Academia Initiatives in Biotechnology (CIA: Biotech 13).

48. Touraud, E.; Roig, B.; Sumpter, J. and Coetsier, C. (2011). Drug residues and endocrine disruptors in drinking water: Risk for humans? International Journal of hygiene and environmental health. 214(8): 437-441.

49. Vieno, N.; Tuhkanen, T. and Kronberg, L. (2006). Removal of Pharmaceuticals in Drinking Water Treatment: Effect of Chemical Coagulation. Environmental Technology. 27(2):183-192.

50. Wang, S. 2008. A comparative study of Fenton and Fenton-like reaction kinetics in decolourisation of wastewater. Journal of Dyes and Pigments, 76(3), 714-720.

51. Yao, J. H.; Niu, D.K.; Li, Z.J.; Liang, Y.C. and Zhang, S.Q. 2010. Effects of antibiotics oxytetracycline on soil enzyme activities and microbial biomass in wheat rhizosphere. Sci Agric Sin. 43:721-728. 